
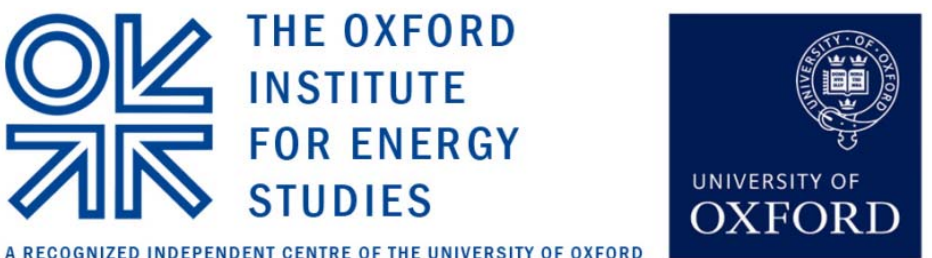

\title{
OPEC: What Difference has it Made?
}

\author{
Bassam Fattouh* Lavan Mahadeva*
}

January 2013

MEP 3

- Oxford Institute for Energy Studies and School of Oriental and African Studies (SOAS), University of London. Address: 57 Woodstock Road, Oxford OX2 6FA, United Kingdom; Tel: +44 (0)1865 311377; Fax: +44 (0)1865 310527; email: bassam.fattouh@oxfordenergy.org.

^ Oxford Institute for Energy Studies. Address: 57 Woodstock Road, Oxford OX2 6FA, United Kingdom; Tel: +44 (0)1865 311377; Fax: +44 (0)1865 310527; email: lavan.mahadeva@oxfordenergy.org. 
The contents of this paper are the authors' sole responsibility. They do not necessarily represent the views of the Oxford Institute for Energy Studies or any of its members.

Copyright $(2013$

\section{Oxford Institute for Energy Studies}

(Registered Charity, No. 286084)

This publication may be reproduced in part for educational or non-profit purposes without special permission from the copyright holder, provided acknowledgment of the source is made. No use of this publication may be made for resale or for any other commercial purpose whatsoever without prior permission in writing from the Oxford Institute for Energy Studies.

ISBN 978-1-907555-67-1 


\section{Contents}

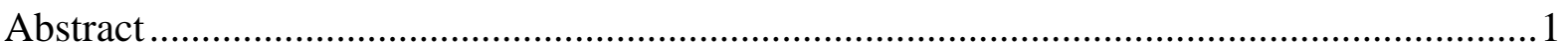

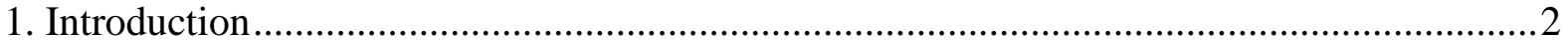

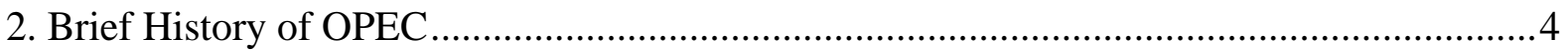

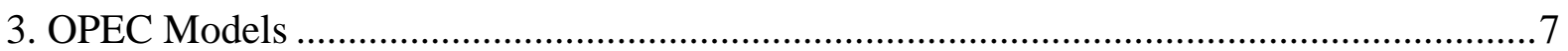

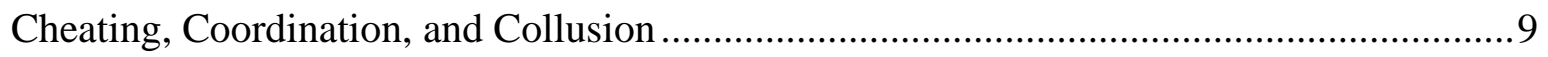

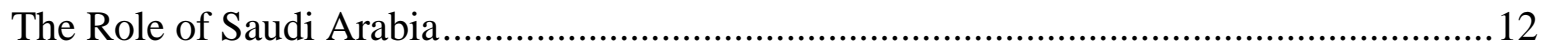

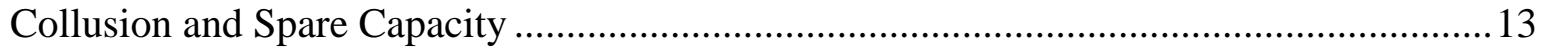

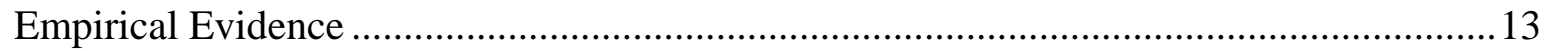

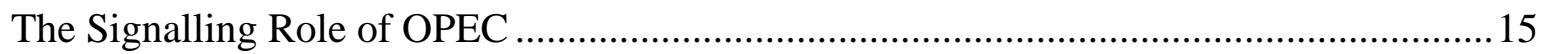

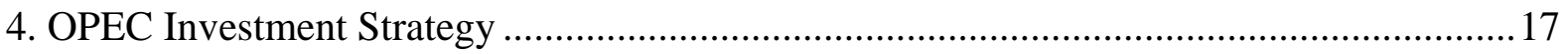

5. OPEC, Rents, and Oil Substitution Policies .....................................................................18

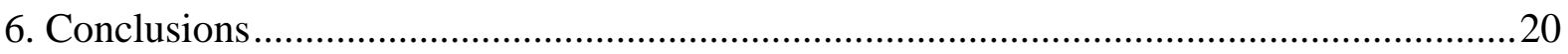

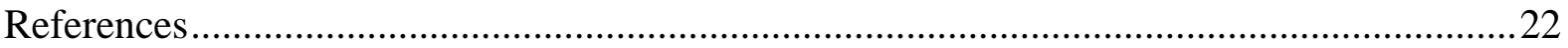




\begin{abstract}
The main purpose of this paper is to review the evolution of OPEC models and to link this evolution to some key events in the oil market. Our main conclusion is that OPEC's pricing power varies over time. There are many instances in which OPEC can lose the power to limit oil price movements either up or down. Such changes in pricing power are brought about by market conditions and can occur both in weak and tight market conditions. Because of OPEC's varying conduct, there is no single model that fits its behaviour and hence analysts have been forced to choose from a wide range of models to explain certain episodes. The empirical literature has not been successful in distinguishing between the various competing models, as these models offer very similar predictions.
\end{abstract}

Keywords: OPEC Models; Oil Prices; Pricing Power; Collusion; Rent Distribution.

JEL-Classification: L11; Q30; Q40. 


\section{Introduction}

Since the 1973 oil price shock, the history, ${ }^{1}$ behaviour, and pricing power of the Organization of Petroleum Exporting Countries (OPEC) have all received considerable attention in the academic literature. One view which prevails is that although OPEC has survived for more than 50 years, it has had little effect on either the oil price or oil market dynamics. Rather, for some, the oil price is seen as being determined in a globally competitive market. An alternative view is that OPEC has been successful in cartelizing the oil market and in using its power to raise the oil price above competitive levels by restricting output. On the other hand, there is the view that OPEC pricing power is not constant, and tends to fluctuate depending on the interaction among OPEC members and on oil market conditions. ${ }^{2}$ The swing in pricing power became very apparent in the events that surrounded the oil price collapse in 1998, which saw the Dubai price, the benchmark for exports to Asia, decline from around \$20 per barrel in early November 1997 to less than \$12 per barrel in March 1998 and averaging around \$10 per barrel in December 1998. At that time, OPEC seemed to have lost its ability to defend oil prices, and many analysts predicted its demise. This view of an ineffective OPEC was, however, reversed only a few months later, and many observers consequently regarded the events of 1998 to have ushered in a new era of cooperation among its members. During March 1998 and March 1999, OPEC embarked on two production cuts in an attempt to put an end to the slide in the oil price. These production cuts were implemented with a high level of cohesiveness among members, contradicting the view that OPEC was not able to collude. By the end of 1999, the Dubai price had risen to \$23 per barrel.

The divergent views about OPEC pricing power have resulted in a wide range of OPEC models. These range from classic textbook cartel, to wealth-maximizing monopolist (Pindyck, 1978a), to three-block cartel (Eckbo, 1976), to two-block cartel (Hnyilicza and Pindyck, 1976), to clumsy cartel (Adelman, 1980), to dominant firm (Salant, 1976; Mabro, 1991), to loosely co-operating oligopoly (Griffin, 1985), to residual firm monopolist (Adelman, 1982), to bureaucratic cartel (Smith, 2005), to competitive models (MacAvoy, 1982; Crémer and Salehi-Esfahani, 1989, 1991). Many of these models were developed to explain key historical events, and in response to changes in key producers' behaviour. The OPEC price war in 1985-6 resulted in many of the 1970s models - those that considered

\footnotetext{
${ }^{1}$ For a historical account of OPEC see Skeet (1988), Terzian (1985), Seymour (1980), Parra (2004).

${ }^{2}$ See for instance Griffin and Nielson (1994), Geroski et al. (1987), Almoguera et al. (2011).
} 
OPEC as a rational wealth-maximizing monopolist or as a monolithic group - being revised. The models of the 1980s and 1990s had to incorporate new elements such as the interaction between OPEC members, price wars, output sharing, the issues of cheating and coordination, the conditions under which OPEC members can collude, and the special role of Saudi Arabia within OPEC. ${ }^{3}$ In the 2000s, the entry of financial players in massive numbers, and the increasing role of futures markets in the price formation process, prompted some studies to consider the signalling role of OPEC. ${ }^{4}$

One of the objectives of this paper is to review the evolution of OPEC models and to link this evolution to some key events in the oil market. Our main conclusion is that OPEC's pricing power is not constant and tends to vary over time. There are many instances in which OPEC can lose the power to influence oil prices. Such changes in pricing power are brought about by market conditions and can occur both in weak and tight market conditions. A second conclusion is that because of OPEC's varying conduct, there is no single model that fits its behaviour and hence analysts have been forced to choose from a wide range of models to explain certain episodes. The empirical literature has not been successful in narrowing the gap between the various competing models (Smith, 2005). Griffin’s (1985) observation in the mid-1980s that empirical studies tend to 'reach onto the shelf of economic models to select one, to validate its choice by pointing to selected events not inconsistent with [that] model's prediction' still dominates the empirical approach to studying OPEC’s behaviour.

One of the challenges faced by any collusive behaviour is the issue regarding entry of new competitors. Although OPEC as an organization does not coordinate its members' investment plans, many OPEC countries have been protected by strong barriers to entry, which stem from ownership and control of the bulk of low-cost oil reserves. By limiting investment in their oil sector, OPEC members can control the future flow of oil supplies into the market. They also shift the burden of meeting the demand for the marginal barrel onto high-cost producers. Another objective of this paper is to analyse how OPEC members' investment decisions can affect the oil market structure and the behaviour of the oil price.

\footnotetext{
${ }^{3}$ See for instance, Geroski et al. (1987), Griffin and Neilson (1994), Hyndman (2008), Griffin and Xiong (1997).

${ }^{4}$ See for instance, Fattouh (2007) and Brunetti et al. (2011).
} 
Driven by energy security and climate change concerns, many consuming countries have been pursuing policies to decrease the carbon content of their energy mix. Such policy measures can have large impacts on long-term oil demand and hence on the share of rent captured by OPEC producers. The literature often ignores the impact of such policies on OPEC behaviour. ${ }^{5}$. 'Another objective of this paper is thus to analyse the options that OPEC faces in dealing with oil substitution policies and with the long-term effectiveness of such options.

\section{Brief History of OPEC}

OPEC was formed in September 1960 by five oil-producing developing countries (Iran, Iraq, Kuwait, Saudi Arabia, and Venezuela) with the objective:

... to coordinate and unify petroleum policies among Member Countries, in order to secure fair and stable prices for petroleum producers. ${ }^{6}$

At that time, the international oil industry - outside the USA, Canada, the USSR, and China was characterized by the dominant position of the large multinational oil companies known as the 'Seven Sisters'. ${ }^{7}$ Host governments did not participate in the production or pricing of crude oil, acting only as competing sellers of oil concessions, and in return they received a stream of income through royalties and income taxes.

Each of the Seven Sisters was vertically integrated and had control of both upstream operations (exploration, development, and production of oil) and, to a significant but lesser extent, downstream operations (transportation, refining, and marketing). At the same time, they controlled the rate of supply of crude oil going into the market through joint ownership of companies that operated in various countries. Such vertical and horizontal linkages enabled the multinational oil companies to control the bulk of oil exports from the major oilproducing countries and to prevent large amounts of crude oil accumulating in the hands of sellers, thus minimizing the risk of sellers competing to dispose of unwanted crude oil to independent buyers and thus pushing prices down (Penrose, 1968). At the heart of the concession system was the concept of a 'posted' price, which was used by the oil companies to calculate the stream of revenues accruing to host governments. Being a fiscal parameter,

\footnotetext{
${ }^{5}$ There have been some exceptions such as Ghanem et al. (1999) and Loulou et al. (2008).

${ }^{6}$ OPEC website: www.opec.org/opec_web/en/about_us/23.htm; accessed 14 January 2013.

7 The Seven Sisters comprised Anglo-Persian Oil Company (now BP); Gulf Oil, Standard Oil of California (SoCal) and Texaco (now Chevron); Royal Dutch Shell; and Standard Oil of New Jersey (Esso) and Standard Oil Company of New York (Socony) (now ExxonMobil).
} 
the posted price did not respond to the usual market forces of supply and demand and thus did not play any allocation function. The formation of OPEC in 1960 was an attempt by member countries to prevent the decline in the posted price (Skeet, 1988) ${ }^{8}$ and thus for most of the 1960s, OPEC acted as a 'trade union' whose main objective was to prevent the income of its member countries from falling.

Between 1965 and 1973, global demand for oil increased rapidly, with an average annual increase of more than $3 \mathrm{mb} / \mathrm{d}$ (BP Statistical Review 2012). Most of this demand increase was met by OPEC countries, which increased their share in global crude oil production from 44 per cent in 1965 to 51 per cent in 1973. These oil market conditions created a strong sellers' market and significantly increased the power of OPEC governments relative to that of the multinational oil companies. In September 1970 the Libyan government concluded an agreement in which oil companies agreed to pay income tax on the basis of an increased posted price and to make retrospective payments to compensate for the lost revenue since 1965. As a result of this agreement, other oil-producing countries made it clear that they would not accept anything less than the terms granted to Libya. The negotiations conducted between OPEC and the multinational oil companies in Tehran in 1971 resulted in a collective decision to raise the posted price and increase the tax rate. ${ }^{9}$

In September 1973, OPEC decided to reopen negotiations to revise the Tehran Agreement and seek large increases in the posted price, but the oil companies refused OPEC's demand and negotiations collapsed. As a result, on 16 October 1973, the six Gulf members of OPEC unilaterally announced an immediate increase in the posted price of Arabian Light crude from \$3.65 to \$5.119. On 19 October 1973, members of the Organization of Arab Oil Producing Countries (less Iraq) announced production cuts of 5 per cent of the September volume, and a further 5 per cent per month, following the 1973 October War between Israel and Egypt and Syria. In December 1973, OPEC raised the posted price of Arabian Light further to \$11.651. This jump in price was unprecedented. More importantly, the year 1973 represented a dramatic shift in the balance of power towards OPEC. For the first time in its history, OPEC assumed a unilateral role in setting the posted price (Terzian, 1985).

\footnotetext{
${ }^{8}$ Facing competitive pressures from independent oil producers, multinational oil companies decided to cut the posted price in 1959 and 1960. The US decision to impose mandatory import quotas, which increased competition for outlets outside the USA, was an additional factor that placed downward pressure on oil prices. ${ }^{9}$ These decisions are known as the 'Tripoli-Tehran' Agreements.
} 
The oil industry also witnessed another major transformation in the early 1970s when some OPEC governments stopped granting new concessions and started to claim equity participation in their existing concessions, with a few opting for full nationalization. Equity participation and nationalization profoundly affected the structure of the oil industry. Multinational oil companies lost large reserves of crude oil and found themselves increasingly dependent on OPEC supplies.

The decline in oil demand in the mid-1980s, caused by a worldwide economic recession, and the growth in non-OPEC crude oil production, in response to higher oil prices and the application of new technologies, represented major challenges to OPEC's administered pricing system and were ultimately responsible for its demise. New discoveries in non-OPEC countries meant that significant amounts of oil began to reach the international market from outside OPEC. This growth in supply also led to an increase in the number and diversity of crude oil producers who were setting their prices in line with market conditions - hence proving to be more competitive. New suppliers who ended up having more crude oil than was required by contract buyers secured the sale of all their production by undercutting OPEC prices in the spot market. Buyers, who became more diverse, were attracted to these offers of competitive prices. With the continued decline in demand for its oil, OPEC saw its own market share in the world's oil production fall from 51 per cent in 1973 to 28 per cent in 1985. OPEC's introduction of a formal quota system in 1982 (still in operation today) did not help reverse the slide in the oil price. The loss of market share and low prices both proved to be costly for OPEC producers, especially Saudi Arabia, which decided to abandon the administered pricing system in 1985.

Although, over the years, OPEC membership has increased (currently there are 12 members), OPEC's share of global production remained relatively stable for most of the 1990s and 2000s, increasing slightly to around 43 per cent in 2011. This share of output is relatively small compared to the size of its reserves, which stood at more than 80 per cent of the world's proven reserves in 2011. What gives OPEC its prominence, however, is its dominant position in the international trade of crude oil, where OPEC's exports constituted around 60 per cent of the world's crude oil exports in 2011, with the share expected to rise as oil demand growth shifts to oil-poor Asia (OPEC, 2012). Furthermore, spare capacity is concentrated in OPEC, particularly in the three Gulf Cooperation Council (GCC) member states (Saudi Arabia, Kuwait, and the UAE), with Saudi Arabia holding the bulk of the 
world's available spare capacity. This has allowed Saudi Arabia to act as a swing producer, filling the gap at times of oil supply disruptions and adjusting its output to balance the market.

\section{OPEC Models}

In many textbooks, OPEC is often used as a classic example of an international cartel. ${ }^{10}$ In the classical monopolist model, the first-order condition can be written as:

$$
M C=P\left(1-\frac{1}{e}\right)
$$

where $P$ is the oil price, $M C$ is the marginal cost, and $e$ is the elasticity of oil demand. Given that oil demand is highly inelastic in the short term, OPEC can set the oil price well above the marginal cost. In this static model, OPEC is not concerned about the impact of high oil prices on long-term demand, or about competition from the fringe. While the monopoly model is static in nature, it has been used to predict the collapse of OPEC. Back in 1974, Friedman argued that:

The initial quadrupling of the price of crude oil after the Arabs cut output was a temporary response that has been working its own cure. Higher prices induced consumers to economize and other producers to step up output ... In order to keep prices up, the Arabs would have to curtail their output to zero; they would not for long keep the world price of crude at $\$ 10$ a barrel. Well before that point the cartel would collapse. ${ }^{11}$

If Friedman can anticipate the potential responses and long-term impacts of high oil prices, why doesn't OPEC? Shouldn't OPEC be concerned about long-term demand destruction and how best to optimize the use of its reserves over time? It became clear that the characterization of OPEC as a classic monopolist in a static framework, and the treatment of oil as a 'standard' commodity, have many limitations and it was thus important to introduce some inter-temporal dimension into OPEC models.

The literature on exhaustibility helped to introduce two key insights in oil market models. First, the oil market should be analysed within a dynamic context: oil production and consumption in one period affect production and consumption in future periods. Second, oil, as a non-renewable resource, commands a resource rent. Thus, unlike standard goods, the market price for oil is not equalized with the marginal cost. This positive premium (also known as the scarcity rent) is the reward that the resource holders obtain for having retained

\footnotetext{
${ }^{10}$ See for instance, Mankiw (2011).

${ }^{11}$ Newsweek 4 March 1974.
} 
their stock up until the point at which it is sold. Thus, oil prices above the marginal cost (or the cost of extraction and development) should not be taken as evidence of cartel behaviour.

Hotelling's pioneering work (1931) was mainly concerned with the following question: given demand behaviour and the initial stock of the non-renewable resource, how much of the resource should be extracted every period in order to maximize the profit for the owner of the resource? Hotelling proposes a very intuitive and powerful theory to address this question. With $r$ as the real risk-free interest rate on investment in the economy, assuming no extraction costs and given a market price per unit of resource, Hotelling shows that in a competitive market, the optimum extraction path would be such that the price of a non-renewable resource will rise over time at the interest rate $r$. Only then will the gains from delayed extraction equal the opportunity cost of extracting now and investing the proceeds at the safe return.

Hotelling also presented the solution for a monopolist. Under certain conditions, the price trajectory under monopoly is different from that of a competitive market, in that the marginal revenue and not the price should increase at the interest rate. Initially the price path of a rationalist monopolist will be higher than the competitive price path, as the monopolist takes advantage of the relatively lower price elasticity in the earlier periods to restrict output and charge a higher price. But at some stage, the monopoly price will fall below the competitive price. This allows OPEC to achieve sufficiently large gains to offset the costs associated with cartelization (Pindyck, 1978a). In these models, the monopolist production trajectory is longer than that of a competitive resource owner and hence the monopolist is a 'conservationist'. Pindyck (1978b) adapted the model to allow the resource owner to choose how much to invest in getting reserves ready to extract, as well as how much to extract. Prices increase more slowly than in the Hotelling case, because exploratory effort depends on the level of reserves. Also, investment is delayed longer in a monopolist setting than a competitive one (at least as long as reserves are still plentiful).

It is important to note that even in models of competitive behaviour, OPEC can restrict output, but for reasons other than collusive behaviour. ${ }^{12}$ Some early studies explained production cuts and the consequent oil price rise in the 1970s in terms of the transfer of

\footnotetext{
${ }^{12}$ See for instance Crémer and Salehi-Isfahani (1989).
} 
property rights from international oil companies to producing governments that tend to have lower discount rates (Johany, 1980; Mead, 1979). MacAvoy (1982) attributes price increases to supply disruptions caused by political events. Other studies stress that oil production decisions are made with reference to investment requirements and budgetary needs, which in turn depend on the absorptive capacity of the domestic economies and imperfections in international markets. Constraints on absorptive capacity give rise to a supply curve which is backward bending (Teece, 1982), with the price moving between a high- and low-price equilibrium, depending on where the supply and demand curves intersect and on expectations about the long-term price (Crémer and Salehi-Isfahani, 1989). ${ }^{13,14}$

\section{Cheating, Coordination, and Collusion}

One limitation of these early models is the treatment of OPEC as a single actor. In reality, OPEC consists of a group of countries with different oil reserve bases and divergent political, social, and economic systems. To account for this fact some models split OPEC members into subgroups based on their time preference and endowment. For instance, Eckbo (1976) splits OPEC into three groups: hard core, the price pushers, and the expansionist fringe. ${ }^{15} \mathrm{He}$ finds that countries with low discount rates and high reserve bases will choose a lower price path than the price pushers. In similar vein, Hnyilicza and Pindyck (1976) divide OPEC into savers (countries with low discount rates) and spenders (countries with high discount rates) and analyse the interaction between these two groups using the theory of cooperative games. ${ }^{16}$ A cooperative solution for this game is feasible if the net incremental gains from cooperation are set in proportion to the losses made in case of non-cooperation. Hnyilicza and Pindyck (1976) find that for an optimal outcome, OPEC members should not produce simultaneously: spenders would produce first while savers initially keep their reserves underground. The authors, however, recognize that such an outcome is not politically feasible.

\footnotetext{
${ }^{13}$ If price increases are expected to be temporary, producers will react by increasing production to take advantage of the temporary price rise. Thus, in empirical models, one should include a measure of long-term oil price expectations rather than the current price, as in Griffin (1985).

${ }^{14}$ The empirical evidence in support of the target revenue theory has been mixed at best. Early studies such as Griffin (1985) find no support for the target revenue model while Alhajji and Huettner (2000a) find that investment and budgetary needs do not affect the production of oil in free-market economies (OPEC or nonOPEC), but they do affect production decisions of the more centrally planned, isolated, and oil-dependent economies. Ramcharran (2001) estimates a modified version of Griffin's (1985) target revenue model and extends the data from 1973 to 2000 . His results are not supportive of the strict version of the target revenue model, however, he finds evidence of negative and significant elasticity of supply, which he interprets as support for the partial version of the target revenue model.

${ }^{15}$ See Houthakker (1979) and Griffin and Steel (1986) for three-part cartel model.

${ }^{16}$ See Tourk (1977) and Aperjis (1982) for two-part cartel models.
} 
While these early studies provided some interesting insights on the interaction between OPEC members, some controversial points remained - one key issue being that of output sharing within OPEC. After all, according to these models, the outcome of a cooperative game will depend on the decision of how to share output, which in turn depends on the bargaining power of individual members. Statements such as '[OPEC members] will have a lot to argue about' (Hnyilicza and Pindyck, 1976) are not very useful in this context.

As we discussed earlier, OPEC's introduction of formal production quotas in 1982 and the 1985 decision to abandon its price setting power can be considered as turning points in the history of the Organization. Between 1973 and 1985, OPEC exercised the ultimate pricing power by setting the marker price. By fixing the price, OPEC had to live with variable volumes of production. With the continued decline in demand for its oil in early 1980, OPEC saw its market share in the world's oil production fall from 51 per cent in 1973 to 28 per cent in 1985. Under these pressures, disagreements within OPEC began to surface. Saudi Arabia, OPEC's biggest producer, lost market share with every increase in the marker price and hence opposed them. Other OPEC members pushed for large price increases - while at the same time putting additional oil in the market in an attempt to boost revenues. OPEC's introduction of a formal quota system proved to be ineffective in preventing production rising above quotas (in other words 'cheating') and it was becoming clear by the mid-1980s that OPEC was losing its power to set the oil price. Saudi Arabia's attempts to defend the marker price resulted in a large loss of market share: the demand for Saudi oil declined from 10.2 $\mathrm{mb} / \mathrm{d}$ in 1980 to $3.6 \mathrm{mb} / \mathrm{d}$ in 1985 . This decline in production volumes and loss of market share proved to be very costly for Saudi Arabia, which decided to abandon the administered pricing system in 1985 , allowing the country to recover its lost share through the netback pricing system, which provided oil companies with a guaranteed refining margin even if oil prices were to collapse (Mabro, 1986). ${ }^{17}$ Under this system, refineries had the incentive to run at a high capacity, which led to an oversupply of petroleum products, forcing down the crude oil price. The price war that followed led to the collapse in crude oil prices.

\footnotetext{
${ }^{17}$ Netback pricing involved a general formula in which the price of crude oil was set equal to the ex post product realization minus refining and transport costs. A number of variables had to be defined in a complex contract. This included: the set of petroleum products that the refiner could produce from a barrel of oil, the refining costs, transportation costs, and the time lag between loading and delivery.
} 
These events prompted analysts to take a fresh look at OPEC's behaviour, in particular at the role of Saudi Arabia within the Organization. Models of OPEC as a wealth-maximizing rational monopolist lost much appeal. As noted by Pindyck

... from a theoretical point of view models of OPEC oil pricing have reached practical limits as tools of analysis ... economic rationality probably applies less to OPEC than to many other economic agents (quoted in Gately, 1984).

Instead, OPEC was seen as an organization, which adjusted its output through the quota system to keep prices above a 'certain floor' that did not necessarily optimize OPEC revenues. As noted by Mabro (1991):

... the revenue maximization objective which theory postulates and core producers would dearly like to achieve is not credible. One has to become content with a second best: to obtain through the pricing policy more revenues than would have accrued under a competitive market structure. This more may be much better than nothing but is likely to be very different from the optimum.

The 1980s events also showed clearly the limitations of modelling OPEC as a homogenous group. Lack of compliance by some OPEC members pushed others to treat these members as being non-OPEC. OPEC needs not only to agree on the total amount of oil to be produced, but also on how to divide it between individual members. However, OPEC does not have a formal monitoring system or disciplinary mechanisms in place. Thus, violations are usually not detected instantly and even if they are, OPEC is unable to punish, and thus force, member countries to abide by the agreed quotas (Kohl, 2002; Libecap and Smith, 2004). These problems become more acute when the required cuts are significant, as small OPEC members usually find it difficult to reduce their production on a pro rata basis - the system adopted by OPEC over the years (Gately, 1989). Widespread cheating and lack of monitoring and disciplinary mechanisms have raised doubts as to whether OPEC is able to collude to restrict output, leading some to conclude that the oil market can be best described as competitive. ${ }^{18}$

However, game theory suggests that even in the absence of a formal disciplinary mechanism, such collusion could still work if implicit threats forced members to abide by the agreed quotas. Stigler (1964) argues that price wars are often a signal of the collapse of collusion. In Porter (1983a, b) and Green and Porter (1984), on the other hand, price wars represent the equilibrium outcome of a dynamic non-cooperative game. Price wars are the solution to the problems of imperfect information that plague OPEC. They are also credible means of communicating and signalling to other firms - hence price wars can be strategic in nature.

\footnotetext{
${ }^{18}$ See for instance, Verleger (1987).
} 


\section{The Role of Saudi Arabia}

The events of the 1980s highlighted the key role of Saudi Arabia within OPEC. Saudi Arabia holds the largest oil reserve base; it accounts for a large share of global production; it is the only country that maintains ample spare capacity; and it restricts foreign investment in upstream oil. Moreover, its output is negatively correlated with that of other OPEC producers and its output has been highly volatile in comparison to other countries, even though Saudi Arabia did not experience the political shocks affecting its neighbouring countries such as Kuwait and Iraq (Nakov and Nuño, 2013). Given these features, many studies have modelled Saudi Arabia as the 'dominant producer', with the remaining producers (both OPEC and nonOPEC) as the competitive fringe. As a dominant leader, Saudi Arabia sets its output in anticipation of the reaction of the fringe and maximizes its profits based on the residual demand.

Despite this prevalent view of Saudi Arabia in the literature, the evidence has not been very supportive of the 'dominant producer' model. ${ }^{19}$ Rather than acting as a dominant producer, Griffin and Neilson (1994) find evidence that Saudi Arabia opted for a tit-for-tat strategy that punishes members for producing above their quotas and rewards them for compliance. They identify three strategies for Saudi Arabia: the Cournot strategy, the swing producer, and the tit-for-tat strategy. As long as Saudi Arabia earns more than Cournot profits, it will be willing to tolerate deviations from the quota and at times may act as a swing producer to earn profits in excess of the Cournot equilibrium level. However, if cheating becomes flagrant, Saudi Arabia will punish the cheaters by increasing its output until everybody gets Cournot profits. Proponents of this view point to two recent episodes that are consistent with Saudi Arabia's adoption of a tit-for-tat strategy: in 1985 when Saudi Arabia boosted its supply in an attempt to increase its market share and in 1998 when Saudi Arabia responded to Venezuela's increase in production and rapid capacity expansion by increasing its own output. In both cases Saudi Arabia played the role of the discipliner - increasing its production and punishing cheaters - to maintain the cohesiveness of OPEC.

\footnotetext{
${ }^{19}$ There are many variants of the dominant firm model that include OPEC, Core OPEC, and Saudi Arabia as a dominant producer. Smith (2005) finds no evidence in support of a dominant producer and concludes that 'If the Kingdom has assumed the role of Stackelberg leader, dominant firm, or swing producer, it must not have been pursued with enough vigor and continuity, either before or after the quota system was adopted, to have left a discernible pattern in the data'. Even Mabro (1998), who has been a strong proponent of the dominant producer theory, acknowledged that against all expectations, Saudi Arabia has been performing the role of a fixed volume supplier that does not vary output according to changes in oil demand, noting that from 1992 to the first half of 1997 the Kingdom maintained an almost fixed production of $8 \mathrm{mb} / \mathrm{d}$. Alhajji and Huettner (2000b) find that Saudi Arabia's behaviour is only consistent with the dominant producer model for the period 1973-2004.
} 


\section{Collusion and Spare Capacity}

Almoguera et al. (2011) find that prior to 1990 there was evidence of collusion, but after the first Gulf War and until 2000 OPEC entered into a period of non-cooperation. This should not come as a surprise. In addition to the political backdrop that increased political tensions between producers, the 1990s were particularly bad for the oil market: between 1991 and 1998, OPEC was left with large excess capacity due to slow growth in demand. There is a large literature on whether firms find it more difficult to collude during booms or recessions. ${ }^{20}$ The main conclusion from that literature is that changes in demand conditions affect the one-shot deviation gains, the losses of future collusive profits, and the future cost of being punished, which directly affect the sustainability of collusive outcomes. Haltwinger and Harrington (1991) find that under certain assumptions of constant and symmetrical marginal costs, a firm's incentives to deviate are stronger when future demand is falling: the value of the foregone collusive profits is smaller when demand is falling than when it is rising. Thus, according to their model, it is more difficult to sustain collusion when demand is falling.

This clear-cut result is less pronounced if capacity constraints are introduced into the model (Brock and Scheinkman, 1985; Fabra, 2003). On one hand, producers may be less able to expand supply to punish defectors, making it harder to sustain collusion in a boom. On the other hand, defectors may not be able to expand their own production to realize the large short-term deviation gains that motivate their break-out. According to this strand of the literature, the relationship between excess capacity and the degree of collusion is not unambiguous. However, Compte et al. (2002) show that these studies critically assume that all firms have the same maximum capacity - implausible in the case of OPEC. The introduction of asymmetry in capacity makes collusion more problematic when excess capacity is large. Collusion is also hard to sustain in a downturn because there are important costs of maintaining a ready excess capacity, even for Saudi Arabia.

\section{Empirical Evidence}

The existing empirical evidence has not helped narrow the gulf between divergent views on OPEC as the competing models of OPEC behaviour offer predictions that are difficult to distinguish from each other. The evidence is therefore often consistent with wide range of

\footnotetext{
${ }^{20}$ Rotemberg and Saloner, 1986; Haltwinger and Harrington, 1991; Staiger and Wolak, 1992; Bagwell and Staiger, 1997; Feuerstein, 2005).
} 
conflicting models (Smith, 2005). Empirical models can be divided broadly into two groups: pricing and output models.

If OPEC exercises market power, then this should be reflected in a significant deviation between the oil price and the marginal cost. Based on this observation, it is possible to identify a wide range of behaviour ranging from non-cooperative behaviour; to Cournot competition in the presence of a competitive fringe; to Cournot competition without a fringe; to cooperative cartel in the presence of a competitive fringe; to an efficient cartel without a fringe (Almoguera et al., 2011). Each of these models entails a different relation between price and marginal cost. However, the power of empirical tests to distinguish between these various models is inherently difficult. As shown by Smith (2005), the power to distinguish between competition and collusion depends largely on the quality of estimates of marginal cost and demand elasticity. Furthermore, in these models, it is not clear whether to attribute the difference between price and marginal cost to scarcity rent or to monopoly profits.

Output models, on the other hand, examine the production behaviour of OPEC individual members. Griffin (1985) uses a simple regression that links the production of an individual country to the oil price and other members' production. A significant relationship between an individual country's output and that of OPEC would indicate market-sharing behaviour and hence evidence that the market is cartelized. Griffin (1985) finds support for market sharing, but only for partial market-sharing, which suggests that 'OPEC is a looser cartel' . ${ }^{21}$ In similar vein, Gulen (1996) argues that if OPEC behaves as a market sharing cartel, then an individual member's output should run in parallel with that of the other members. However, evidence of parallel movements is also consistent with competitive models - for example if all producers react to changes in market fundamentals. Smith (2005), on the other hand, focuses on whether an individual member's output offsets or compensates for production changes in other members. He argues that in a Cournot oligopoly model, faced with an idiosyncratic shock that causes the output of one individual member to decline, the other members will compensate by increasing production. In contrast, in competitive markets, there is no interdependence in the production of various producers. Based on this, Smith (2005) identifies a spectrum of market models, ranging from a cartel to perfect competition, and finds that

\footnotetext{
${ }^{21}$ Jones (1990) extends the data from 1983 to 1988 and reaches similar results, though he finds more support for the competitive hypothesis.
} 
traditional explanations of OPEC behaviour do not hold. Instead, he describes OPEC as a cartel, but one that is weighed down by the cost of establishing consensus.

Another complication is that OPEC pricing power varies, depending on market conditions and on producers' behaviour. The most interesting models are those that allow for a change in conduct. In Geroski et al. (1987), collusion is rarely perfect and some producers may change their behaviour in response to a rival's previous actions. Their empirical results show that varying-behaviour models tend to out-perform constant-conduct models. Similarly, Almoguera et al. (2011) find many switches between collusive and non-cooperative behaviour in the period 1975-2004, indicating that the ability to collude is not static. These empirical results indicate that changes in oil prices can be explained not only in terms of shifts in oil market balances, but also by changes in the conduct of market players.

\section{The Signalling Role of OPEC}

The increasing participation of financial investors and the increasing role of financial layers in the oil price formation process (Fattouh et al., 2012; Fattouh and Mahadeva, 2012) have been interesting developments in commodities markets in recent years. This has suggested to some analysts that there may be a role for OPEC to influence the oil price through signalling to financial investors. Specifically, OPEC can use announcements of production changes to signal a change in behaviour or to send signals about its preferred price.

Using event study analysis, a few studies have examined the impact of OPEC announcements on oil prices, returns, implied volatility, and realized volatility. ${ }^{22}$ However, the evidence has been inconclusive at best. Brunetti et al. (2011) question whether OPEC 'fair price' pronouncements contain information not already reflected in market prices. They find that these pronouncements have little influence on the market price of crude oil and that they provide little or no news to oil futures market participants. Wirl and Kunjundzic (2004) investigate whether decisions made at the OPEC Conference exert any influence on oil prices. Using data for the period 1984-2001, they found the impact of OPEC decisions on oil prices to be weak and where there was any impact, it was restricted to decisions that call for price increases. The authors argue that this result could be due to three reasons:

(i) sufficient information is leaked prior to the meeting so that the official Conference reveals hardly any new information;

\footnotetext{
${ }^{22}$ See for instance Wirl and Kujundzic (2004),Hyndman (2008), Demirer and Kutan (2010), Horan et al. (2004).
} 
(ii) news show up only in data with higher, say hourly, frequency;

(iii) the Conference lacks credibility that the agreed upon policies will be actually carried out

by the individual member countries (Wirl and Kujundzic, 2004, 60)

The evidence from event study analysis, however, should be treated with caution. Fattouh (2007) argues that, with the growing importance of the futures market in the process of oil price discovery, pursuing output polices has become more complicated. The effectiveness of any policy depends to a large extent on the ability of OPEC to influence participants' expectations. After all, OPEC signals lack credibility, as it is costless to make them ${ }^{23}$ and the market will wait until OPEC implements any cut. For example, in a falling market, OPEC sends a signal to the market about its preferred oil price. If the signal is successful in stabilizing expectations about its preferred price, OPEC will not have to resort to output cuts. Instead, it will continue to meet demand at a price with which the Organization is comfortable, given prevailing market conditions. However, OPEC signals are rarely successful in stabilizing short-term expectations in a falling market. If the announced output cuts are large, financial players start to question whether OPEC will be able to implement them, given internal divisions and the difficulty of sustaining a unanimous production decision in face of falling demand. OPEC does, however, often succeed in implementing necessary production cuts, especially when oil prices fall to very low levels. Such interactions with market players complicate the channels through which OPEC influences the market, creating a time lag - which tends not to be captured by event study analysis - between an OPEC announcement of an output cut and the point at which market players respond to the OPEC signal. This is further complicated by the fact that OPEC's responses to oil price movements are asymmetric. A key objective of OPEC is to avoid oil prices falling below some level deemed unacceptable by its members, rather than to prevent oil prices from rising above certain levels, or to set a price ceiling. Thus, in a rising market, OPEC tends to satisfy demand at the available market-determined prices by adjusting its production; it does not attempt to discount its spare capacity to bring prices down. The perception that OPEC would respond by increasing supply to limit price rises has been important for anchoring short-term expectations about oil prices. In the 2002-8 cycle, uncertainty as to whether OPEC would generate a strong feedback in a rising market contributed to destabilizing expectations and reinforced perceptions of limited feedbacks (Fattouh and Scaramozzino, 2011).

\footnotetext{
${ }^{23}$ See Farrell and Rabin (1996) for a review on Cheap Talk.
} 


\section{OPEC Investment Strategy}

In addition to coordination and cheating, one of the issues facing any collusive behaviour is the issue of entry of new competitors. OPEC has been protected by strong barriers to entry, which stem from ownership and control of low-cost oil reserves. Although production of crude oil from non-OPEC sources expands when OPEC cuts production and prices are high, the scope of expansion remains limited. After all, OPEC still controls the bulk of the world's proven oil reserves.

One standard way of modelling OPEC supply in long-term projections has been to treat it as a residual, often referred to as the 'call on OPEC'. This is the hypothetical amount that OPEC needs to produce to close the gap between anticipated oil demand and non-OPEC supply. In other words, projections of OPEC supply are not based on any behavioural analysis but are derived from a simple accounting formula that balances world demand after taking into account various factors. This approach clearly suffers from major limitations as it is based on two simplistic assumptions: the first is that OPEC always has the incentive to expand output to increase its market share; the second is that OPEC producers can and will undertake the necessary investment to increase capacity. These assumptions, however, are highly questionable. Regarding the first, aggressive plans to expand OPEC output can yield lower pay-offs (Gately, 2004). This result is quite intuitive. Lower prices resulting from a rapid output expansion would lead to decreased revenues, cancelling out the higher output. As to the second assumption, even if OPEC has the incentive to increase market share, the investment needed to attain such a share is substantial, and the investment decision may be affected by a number of other factors. These include: uncertainty about long-term oil demand growth, which increases the option to wait (Dixit and Pindyck, 1994); unfavourable geopolitical factors; sanctions; and the relationship between the government and the national oil company that may lead to low investment in the oil sector.

The decision to restrict investment by holders of low-cost reserves creates a market structure in which both low-cost and high-cost producers co-exist, with implications on oil price behaviour. The oil price can clear within a wide range, depending on oil market conditions: the lower boundary of the range is set by the cost of production in key OPEC members while the upper boundary is set by the potential entry of substitutes. When the market is characterized by predictions of excess demand, potential substitutes and adjustments in 
demand cannot place a cap on the short-term price. Instead in the absence of spare capacity, most of the adjustment is likely to occur through sharp increases in oil prices. Thus, when the majority of OPEC members are producing at or close to their maximum capacity, OPEC has little ability to act to lower the price. This problem can be compounded by market scepticism about OPEC's spare capacity and its ability to raise production. In other words, at times when prices are rising and when OPEC is perceived to be in the control seat, OPEC's power to influence price is weakest.

When the market is characterized by excess capacity, the oil price tends to move towards the lower boundary. As we have argued, in times of declining demand (such as periods of recession), tacit collusion is fragile. This means that prices can fall somewhat below the collusive outcome. Yet experience has shown that collusion may reassert itself powerfully before the competitive price floor is reached. As noted by Mabro:

[OPEC members' ability to] compromise to reach agreement should not be underestimated. It is founded on the belief that all members, including the largest producers, would be worse off without OPEC (Mabro 1986, 19).

\section{OPEC, Rents, and Oil Substitution Policies}

A core feature of oil is that it creates large economic rents, which are often contested between producers and consumers and among the various players in the supply chain. As put by Fattouh and van der Linde (2011):

The sizable economic rents have been a prize deemed worth fighting for, far beyond the normal competition among market players. They have guaranteed persistent involvement by governments everywhere, either as producers or tax collectors.

OPEC producers would like to claim higher rents by maintaining increasingly stringent constraints on investment and supply. Consumer governments would like to capture the rents involved via domestic taxation or equivalently by cap-and-trade systems. Driven by energy security and climate change concerns, many OECD and non-OECD countries have been stimulating the use of renewable energies - often through a combination of regulations, incentives, subsidies, taxation, moral persuasion, and/or a combination of these instruments to change the composition of their energy mix to one with a lower carbon content. Oil substitution policies can have a large impact on long-term oil demand since their impact is cumulative and irreversible. Thus, from OPEC's perspective, taxes on petroleum products and oil substitution policies are seen as discriminatory, tending to dampen oil demand growth, and reducing OPEC's export share in the energy mix in the long term. Taxes also 
raise a distributional issue since consuming countries can capture part of the rent - in most cases this is larger than the share extracted by OPEC producers themselves - through taxation (Allsopp and Fattouh, 2011). ${ }^{24}$

There are few recent studies examining the potential responses of OPEC to oil substitution policies. OPEC can divert a larger part of the rent through raising its prices. Since the easiest oil demand is substituted first, the oil demand remaining is highly inelastic. This could allow OPEC to restrict its output and increase the oil price, to take full advantage of the captive residual oil demand. High oil prices, however, accelerate the pace of demand reduction and may induce consuming governments to pursue oil substitution policies more aggressively. An alternative policy would be for OPEC to anticipate the extent of demand destruction and increase its quota, inducing a decrease in the oil price to generate a rebound in global oil demand and drive out non-OPEC supply. Using simulation analysis, Loulou et al. (2008), however, show that OPEC would derive no advantage from flooding the oil market even if all announced climate change policies were fully implemented, since its own net revenues would decrease in such an event. Simulation results also show that OPEC's profits would be lower in a world of effective climate change policies and that there is only limited scope for OPEC to defend its oil revenue by adopting a firm price strategy consistent with significant production restraint (Ghanem et al., 1999; Loulou et al., 2008). ${ }^{25}$ This has triggered a debate on the green paradox: ${ }^{26}$ OPEC countries feeling threatened by a decline in future prices will respond by increasing production in the short run, reducing prices and increasing oil consumption and thus accelerating global warming. ${ }^{27}$

\footnotetext{
${ }^{24}$ OPEC's approach to climate change policies is also based on the wider concepts of equity: 'Many have already implemented policies to limit the use of petroleum products in order to reduce $\mathrm{CO}_{2}$ emissions. However, OPEC urges fairness and equity in global efforts to curtail carbon emissions'. 'OPEC and the Environment', available at:

www.opec.org/opec_web/static_files_project/media/downloads/press_room/OPEC_Environmental_position.pdf ${ }^{25}$ However, some have argued that the costs in these models are overstated. Barnett et al. (2003) find that losses as a result of climate change policy will not affect OPEC countries in an equal manner and that the losses are not as substantial as many models forecast. They also argue that there is a range of policy measures that could be adopted to lessen any impact the Protocol may have on OPEC.

${ }^{26}$ See for instance, Sinn (2008) and Eichner and Pethig (2009).

${ }^{27}$ The green paradox, however, is not inevitable. For instance, Loulou et al. (2008) find that 'OPEC strategies have almost no impact on the global emissions and climate with and without a climate constraint'.
} 


\section{Conclusions}

Over its 50-year history, OPEC's role has continued to evolve, reflecting changes in the broader political scene and in oil market conditions. The formation of OPEC in 1960 was an attempt by member countries to prevent the decline in the posted price and thus for most of the 1960s, OPEC acted as a trade union whose main objective was to prevent the income of its member countries from declining. In 1973, and for the first time in its history, OPEC assumed a unilateral role in setting the oil price. Under severe market pressures, however, it was forced to abandon its price setting power. Against many expectations, the price war in the mid-1980s did not result in the demise of OPEC, but rather highlighted the importance of strategic interaction between OPEC members and between OPEC and non-OPEC producers. Between 1986 and 1998, OPEC assumed various roles but mainly that of a spare capacity manager and swing producer filling the gap caused by supply disruptions. In the 1990s, weak demand growth and large spare capacity diminished OPEC's capacity to collude and in 1998, OPEC had to re-establish its cohesiveness through another price war. Between 2000 and 2008, OPEC acted as a residual supplier, adjusting its output at market-determined prices. From 2008 onwards, Saudi Arabia has increasingly played the role of a signaller to market participants, but with mixed results so far.

The evolution of OPEC's behaviour indicates that its conduct is not consistent. Such behaviour implies that while some (not all) OPEC models can be used to explain key market events, academics are forced to rely on a wide range of models to capture the evolving role of OPEC. This also explains the failure of empirical studies to reach more concrete conclusions: while some empirical models may fit the data quite well in specific periods, they fail miserably in other periods. Hence, this review emphasizes the importance of relying on dynamic models that allow for changes in OPEC's behaviour. Attempts to fit OPEC into one category have failed in the past and will most likely fail as its role continues to evolve.

Our review also shows that while adjusting production and signalling can help OPEC achieve more revenues than through a purely competitive outcome, its power also stems from the ability of its key member countries to restrict the rate of investment into their oil sectors and hence limit the growth of oil supplies. By restricting investment and keeping oil prices relatively high, OPEC allows the entry of high-cost producers, which helps put both a floor (below a certain price high-cost producers don't have the incentive to increase supplies and 
may even cut production) and a ceiling on the oil price (above a certain price high-cost producers have the incentive to increase production, generating a supply feedback). ${ }^{28}$ Within this range, the power of OPEC oscillates depending on the prevailing market conditions. If OPEC's spare capacity is eroded it will become a price taker, and the adjustment in the oil market will occur through sharp upward price movements. In an environment of large surplus capacity, the power to collude declines and the downward pressure on the oil price intensifies. This induces OPEC to collude to prevent the price falling to the cost floor. In normal market conditions, OPEC adjusts its output in an attempt to keep prices within its preferred range.

Finally, our review shows that while OPEC's power is visible in the short term, it is less certain that such pricing power can be maintained in the long term. Taxation, climate change, and energy security policies aimed at reducing the share of oil in the energy mix can erode OPEC's position in the long term, resulting in lower revenue streams for the Organization. This represents a real challenge for OPEC and lies at the heart of a core feature of the oil market: the rent distribution question. The way in which OPEC confronts this challenge will determine both its future evolution and its position in the oil market.

\footnotetext{
${ }^{28}$ High oil prices also encourage the entry of oil substitutes and generate demand feedbacks by reducing oil demand, slowing economic growth, changing consumer behaviour, and accelerating government policies of oil substitution.
} 


\section{References}

Adelman, M. A. (1980). 'The Clumsy Cartel', The Energy Journal, 1(1): 43-53.

Adelman, M. A. (1982). 'OPEC as a Cartel', in OPEC Behavior and World Oil Prices, J. Griffin and D. Teece (eds), London: Allen \& Unwin, 37-57.

Almoguera, P., Douglas, C., and Herrera, A.M. (2011). 'Testing for the Cartel in OPEC: Noncooperative Collusion or Just Non-cooperative?', Oxford Review of Economic Policy, 27:144-68.

Alhajji, A. F. and Huettner, David (2000a). 'The Target Revenue Model and the World Oil Market: Empirical Evidence from 1971 to 1994', The Energy Journal, 21:121-43.

Alhajji, A. F. and Huettner, David (2000b). 'OPEC and World Crude Oil Markets from 1973 to1994: Cartel, Oligopoly, or Competitive?', The Energy Journal, 21, no. 3, 31-60.

Allsopp C. and Fattouh, B. (2011). 'Oil and international energy', Oxford Review of Economic Policy, 27: $33-67$

Aperjis, D. (1982). The Oil Market in the 1980s, OPEC Oil Policy and Economic Development, Cambridge, MA: Ballinger Publishing Company.

Bagwell, K. and Staiger, R. (1997). 'Collusion over the Business Cycle', RAND 28: 82-106.

Barnett, J., Dessai, S., and Webber, M. (2003). 'Will OPEC Lose from the Kyoto Protocol?', Energy Policy, 32: 2077-88.

BP (2012). Statistical Review of World Energy 2012.

Brock, W. A. and Scheinkman, J. (1985). 'Price Setting Supergames with Capacity Constraints', Review of Economic Studies, 52: 371-82.

Brunetti, C., Buyuksahin, B., Robe, M., and Soneson, K. (2011). 'Do OPEC Members Know Something the Market Doesn't? 'Fair Price' Pronouncements and the Market Price of Crude Oil', CFTC and IEA Working Paper, Washington DC and Paris, August 2011.

Compte, O., Jenny, F., and Rey, P. (2002). 'Capacity Constraints, Mergers, and Collusion', European Economic Review, 46(1):1-29.

Crémer, J. and Salehi-Isfahani, D. (1991). Models of the Oil Market, New York: Harwood Academic Publishers.

Crémer, J. and Salehi-Isfahani, D. (1989). 'The Rise and Fall of Oil Prices: A Competitive View', Annales d'Économie et de Statistique, n. 15/16, Institut national de la statistique et des études économiques, Paris: 427-54.

Demirer, R. and Kutan, A. (2010). 'The Behavior of Crude Oil Spot and Futures Prices around OPEC and SPR Announcements: An Event Study Perspective', Energy Economics, 32: 1467-76.

Dixit, A. and Pindyck, R. (1994). Investment under Uncertainty, Princeton: Princeton University Press.

Eckbo, P. L. (1976). The Future of World Oil, Ballinger Publishing Company, Cambridge, Mass.

Eichner, T. and Pethig, R. (2009). 'Carbon Leakage, The Green Paradox and Perfect Future Markets', CESifo Working Paper 2542.

Fabra, N. (2003). 'Collusion with capacity constraints over the business cycle', International Journal of Industrial Organization, 24(1): 69-81.

Farrell, J. and Rabin, M. (1996). 'Cheap Talk', The Journal of Economic Perspectives, 10(3): 103-18.

Fattouh, B., Kilian, L., and Mahadeva, L. (2012). 'The Role of Speculation in Oil Markets: What Have We Learned So Far?, The Energy Journal, Forthcoming. 
Fattouh, B. and Mahadeva, L. (2012). 'Assessing the Financialization Hypothesis', OIES Working Paper 49, Oxford: Oxford Institute for Energy Studies.

Fattouh, B. and Scaramozzino, P. (2011). 'Uncertainty, expectations, and fundamentals: whatever happened to long-term oil prices?', Oxford Review of Economic Policy, 27(1): 186-206.

Fattouh, B., and van der Linde, C. (2011). 'The International Energy Forum: Twenty Years of Producer-Consumer Dialogue in a Changing World', Riyadh International Energy Forum.

Fattouh, B. (2007). 'OPEC pricing power: The need for a new perspective', in Helm, D. (ed.), The new energy paradigm, Oxford University Press, Oxford, UK.

Feuerstein, S. (2005). 'Collusion in Industrial Economics - A Survey', Journal of Industry, Competition and Trade. 5(3):163-98.

Gately, D. (1984). 'A Ten-year Retrospective: OPEC and the World Oil Market', Journal of Economic Literature, 22(3): 1100-1114.

Gately, D. (1989). 'Do Oil Markets Work? Is OPEC Dead?', Annual Review of Energy, 14(1):95-116.

Gately, D. (2004). 'OPEC's Incentives For Faster Output Growth', The Energy Journal, 25(2): 75-96.

Geroski, P. A., Ulph, A. M., and Ulph, D. T. (1987). 'A Model of the Crude Oil Market in which Market Conduct Varies', The Economic Journal, 97: 77-86.

Ghanem, S., Lounnas, R., and Brennand, G. (1999). 'The impact of emissions trading on OPEC', OPEC Review, 23: 79-112.

Green, E., and Porter, R. (1984). 'Noncooperative Collusion under Imperfect Price Information', Econometrica, 52: 87-100

Griffin, J. M. (1985). 'OPEC Behaviour: A Test of Alternative Hypotheses', American Economic Review, 75(5): 954-963.

Griffin, J. M. and Nielson, W. S. (1994). 'The 1985-1986 oil price collapse and afterwards: what does game theory add?', Economic Inquiry, 32(4): 543-61.

Griffin, J. and Steele, H. (1986). Energy Economics and Policy, New York: Academic Press.

Griffin, J. M. and Xiong, W. (1997). 'The Incentive to Cheat: an Empirical Analysis of OPEC. Journal of Law \& Economics', 40(2), 289-316.

Gulen, S. G. (1996). 'Is OPEC a Cartel? Evidence from Cointegration and Causality Tests', The Energy Journal, 17(2), 43-57.

Haltwinger, J. and Harrington, J. (1991). 'The Impact of Cyclical Demand Movements on Collusive Behavior', RAND Journal of Economics 22: 89-106.

Horan, S.M., Peterson, J.H., and Mahar, J. (2004). 'Implied Volatility of Oil Futures Options Surrounding OPEC Meetings', Energy Journal 25 (3): 103-26.

Hnyilicza, E. and Pindyck. R. S. (1976). 'Pricing Policies for a Two-Part Exhaustible Resource Cartel: The Case of OPEC', European Economic Review, 8: 139-54

Hotelling, H., (1931). 'The economics of exhaustible resources', The Journal of Political Economy, 39(2): $137-175$.

Houthakker, H. (1979). 'The Political Economy of World Energy', Harvard Institute of Economic Research, Discussion paper No. 617.

Hyndman, K. (2008). 'Disagreement in bargaining: An empirical analysis of OPEC', International Journal of Industrial Organization, 26(3): 811-28.

Johany, A. (1980). The Myth of the OPEC Cartel: The Role of Saudi Arabia, New York: John Wiley and Sons. 
Jones, C. T. (1990). 'OPEC Behavior under Falling Prices: Implications for Cartel Stability', The Energy Journal, 11, no. 3, 117-29.

Kohl, W. L. (2002). 'OPEC behaviour, 1998-2001', The Quarterly Review of Economics and Finance, 42(2), 209-33.

Libecap, Gary D. and Smith, James L. (2004). 'Political Constraints on Government Cartelization: The Case of Oil Production Regulation in Texas and Saudi Arabia', in How Cartels Endure and How They Fail: Studies of Industrial Collusion, Peter Grossman (ed.). Cheltenham, UK: Edward Elgar Publishing Ltd.

Loulou, R., Labriet, M., Haurie, A., and Kanudia, A. (2008). 'OPEC Oil Pricing Strategies in a Climate Regime, a Two-Level Optimization Approach in an Integrated Assessment', Cahier du GERAD, G, 2008, 71

Mabro, R. (1991). 'OPEC and the Price of Oil', The Energy Journal, 13: 1-17.

Mabro, R. (1976). 'Can OPEC Hold the Line?', in R. Mabro (ed.), OPEC and the World Oil Market: the Genesis of the 1986 Price Crisis, Oxford: Oxford Institute for Energy Studies.

Mabro, R. (1998). 'The Oil Price Crisis of 1998', Working Paper SP 10, Oxford Institute for Energy Studies.

Mabro, R. (1986). Netback Pricing and the Oil Price Collapse of 1986, WPM 10, Oxford: Oxford Institute for Energy Studies, 1986

MacAvoy, P. W. (1982). Crude Oil Prices As Determined by OPEC and Market Fundamentals, Cambridge, MA: Ballinger.

Mankiw, G. (2011). Principles of Economics, 6th Edition, Cengage Learning.

Mead, Walter J. (1979). 'The Performance of Government Energy Regulation', American Economic Review, 69: 352-6.

Nakov, A. and Nuño, G. (2013). 'Saudi Arabia and the Oil Market', Economic Journal, forthcoming.

OPEC (2012). Annual Statistical Bulletin. Available at:

www.opec.org/opec_web/static_files_project/media/downloads/publications/ASB2012.pdf.

Parra, F. (2004). Oil Politics: A Modern History of Petroleum, I.B. Taurus.

Penrose, E. (1968). The Large International Firm in Developing Countries: The International Petroleum Industry, USA: Greenwood Press.

Pindyck, R.S. (1978a). 'Gains to Producers from the Cartelization of Exhaustible Resources', Review of Economics and Statistics, 60: 238-51.

Pindyck, R.S. (1978b). 'The optimal exploration and production of nonrenewable resources', The Journal of Political Economy, 86: 841-61.

Porter, R.H. (1983a). 'A Study of Cartel Stability: The Joint Executive Committee, 1880-1886', Bell Journal of Economics, 14(2):301-14.

Porter, R.H. (1983b). 'Optimal Cartel Trigger Price Strategies', Journal of Economic Theory, 29: 313-18.

Ramcharran, H. (2001). 'OPEC Production under Fluctuating Oil Prices: Further Test of the Target Revenue Theory', Energy Economics, 23: 667-81.

Rotemberg, J. and Saloner, G. (1986). 'A Supergame Theoretic Model of Price Wars during Booms'. American Economic Review,70: 390-407.

Salant, S. (1976). 'Exhaustible Resources and Industrial Structure: A Nash-Cournot Approach to the World Oil Market', Journal of Political Economy, 84: 1079-93. 
Seymour, I. (1980). OPEC Instrument of Change, New York: The Macmillan Press Ltd.

Skeet, I. (1988). OPEC: Twenty-Five Years of Price and Politics, Cambridge: Cambridge University Press.

Sinn, H.W. (2008). 'Public Policies against Global Warming: A Supply Side Approach', International Tax and Public Finance, 15: 360-94.

Smith, J. L. (2005). 'Inscrutable OPEC? Behavioral Tests of the Cartel Hypothesis', The Energy Journal, 26(1): 51-82.

Staiger, B. and Wolak, F. (1992). 'Collusive Pricing with Capacity Constraints in the Presence of Demand Uncertainty', Rand Journal of Economics, 70: 390-407.

Stigler, G.J. (1964). 'A theory of oligopoly', The Journal of Political Economy, 72:44-61.

Teece, D. (1982). 'OPEC Behaviour: An Alternative View', in OPEC Behaviour and World Oil Prices, J. M. Griffin and D. Teece (eds). London: Allen \& Unwin.

Terzian, P. (1985). OPEC: The Inside Story, London: Zed Books Ltd.

Tourk, K. (1977). 'The OPEC Cartel: A Revival of the Dominant Firm Theory', Journal of Energy and Development, 7(2): 321-8.

Verleger, P.K. (1987). 'The evaluation of oil as a commodity', in Energy, Markets and Regulation: Essays in Honor of M. A. Adelman, Gordon, R., Jocoby, H., and Zimmerman, M. (eds), MIT Press, Cambridge, MA.

Wirl, F. and Kujundzic, A. (2004). 'The impact of OPEC Conference outcomes on world oil prices 1984-2001', The Energy Journal, 25(1): 45-62. 